\title{
A POSSIBILIDADE DE RESTRIÇÃO DE ACESSO A BENS PÚBLICOS DE USO COMUM POR QUESTÕES AMBIENTAIS E URBANISTICAS
}

\author{
FLORIANO DE AZELEDO MARQUES NETO*
}

\begin{abstract}
Os contornos juridicos da quéstäo - O choque de pautas constitucionais - A inexistência de privilégio de interesses privados na restrição - A hipótese de restriçäo imposta pela administraçäio no exercicio de poder de polícia - A hipótere de céssáa de uso privativo e condicionado de bem público
\end{abstract}

\section{Os contomos jurídicos da questão}

Cuida-se aqui de questão versante sobre a possibilidade de se impor limitações ao acesso a bens públicas quando envolvidos aspectos ambientais a serem preservados, especialmente praias.

Por serem as praias bens públicos da União, declarados em lei como acessíveis, sempre, a qualquer um do povo. seria írrita limitação ou restrição a este absoluto acesso. Diante deste argumento, seria de rigor que se fizesse cessar, de imediato, todo e qualquer óbice anteposto a este acesso, quanto mais se este odiável empecilho fosse oferecido por particulares possuidores de imóveis situados em loteamento lindeiro às ditas praias. Ao argumento do acesso pleno às aprazíveis paragens marítimas, acrescenta-se o discurso irretorquível de combate à apropriação privada do que é de todos.

Até esta altura, o assunto pareceria cobrir-se do difícil manto do consenso. Ninguém poderia sustentar, nos limites do até aqui relatado, tese contrária àquela que, inapelavelmente, levaria, com a licença dos poetas, à desobstrução da "vereda que levaria o povo ao mar".

Porém, a eventuais demandas judiciais, antepõe-se um dado da realidade, muitas vezes esquecido. Suponhamos, à guisa de exemplo, que as praias por cujo acesso

* Advogado, Doutor em Direito Público pela USP. Professor de Dircito Administrativo da Universidade de São Paulo.

\begin{tabular}{lll}
\hline R. Dir. Adm., & Rio de Janeiro, 235: 273-297, & Jan./Mar. 2004 \\
\hline
\end{tabular}


encontram-se incrustradas em áreas abraçadas por encostas da Serra do Mar e recobertas por uma das últimas áreas de Mata Atlântica, com fauna e flora nativas ainda preservadas. De tal modo que, propiciado o acesso desregrado de veranistas àquela orla, especialmente se tal acesso se dê, como é o irrefreável costume dos banhistas, por meio de veículos automotores, em breve tempo assistiríamos o perecimento daquela reserva ambiental.

$O$ risco aqui aludido constitui premissa do estudo que ora desenvolvemos. E não há porque temer a incidência em erro de pressupostos. Três ordens de razões nos dão a certeza da ameaça ambiental ensejada por um acesso despeiado de turistas àquela área.

O primeiro, fático. Em um só dia - caso concreto que tivemos conhecimento - vigente ordem liminar para abrir irrestritamente o acesso a uma das praias da região, acorreram ao local mais de mil veículo. Este volume de tráfego ocasionou um verdadeiro colapso viário e de parqueamento. Dentre outros danos ocorridos. pode-se aludir a queda de veículo em riacho que abastece de água potável a região. com consequiente vazamento de combustível; o destroçamento de áreas verdes utilizadas indevidamente como estacionamento e o sucumbimento do pavimento das ruas, insuportável que foi o impacto do incomum tráfego na área, mesmo porque tal pavimento, é de se presumir, não foi dimensionado para tal volume de tráfego.

A segunda ordem de argumentos é ambiental. Os diversos estudos ambientais são uniformes em afirmar que a ocupação humana acarreta, em si, riscos à fauna e flora nativas'. Ademais, não parece ser objeto de dúvidas que a alocação, de uma hora para outra, de dois milhares de pessoas numa área de reserva ambiental acarreta riscos para o que os estudiosos chamam de biota. No mínimo, porque a desproporcional presença dos automóveis afeta, é óbvio, o tênue equilíbrio do ecossistemal. interferindo nos processos vitais das espécies vegetais e animais ali presentes. Estes fatores, aliás, vêm sufïcientemente demonstrados nos pareceres técnicos oferecidos no mesmo caso concreto versando sobre o dito impacto ambiental.

A terceira linha de razões, tem natureza urbanística. A regiāo do loteamento implantado junto à praia - área em torno da qual se foca o interesse do presente trabalho - não reúne condições de infra-estrutura apta a acolher a quantidade de turistas ensejada pelo acesso irrestrito à área. A malha viária é sobremodo tímida, pois que a sua ampliação feriria a área protegida. Além de serpentear por área de encosta da Serra do Mar. sabidamente marcada por condições geológicas desfavo-

1 Apenas em sede de exemplo, tome-se a consideração tecida por Diogo Figueiredo Moreira Neto: "a preocupação [com a ecologial se explica se consideramos estes dados impressionantes: na era paleolítica a Terra não abrigara mais que 10 milhöes de homensi na descoberta do Brasil pouco mais que meio bilhão: na nossa Independência, dobrava para um bilhão; no fim da Segunda Grande Guerra Mundial, beirand 3 bilhoes e no ano 2.000 podera ascender a 6 on 7 billowes. E esta mole humana habitará, em swa grande parte. complexos arbanos cada vez maiores. com gigantescos sistemas viários e de serviços en crescente expantsão, reduzindo sensivelmente o espaço propício ao suporte da biosfera planelária (o complexo dos seres vivos, inclusive o homem)", in "Introdução ao Direito Ecológico e ao Direito Urbanistico". Rio de Janeiro, Forense, 1977, pág. 16. 
ráveis. A infra-estrutura de saneamento-básico oferecida pelo poder público é nula. O que há em termos de captação e tratamento de esgotamento sanitário foi implementada e é custeada pelos moradores e donos de lote. sendo dimensionada para absorver a restrita demanda destes. O mesmo ocorre com as condiçỏes de segurança pública, suprida a expensas dos proprietários - que mantên seguranças - e contra as desfavoráveis condições da região - já que a mata favorece as mais diversas práticas delituosas, já tendo ocorrido, por conta da liminar já cassada, vários casos de consumo e tráfico de entorpecentes. até mesmo o nefasto crack.

Deste conjunto de fatores, arrolados em relatório sucinto, é verdade, mas nem por isso menos veemente, depreende-se o fato, ao nosso ver incontroverso, de que o acesso irrestrito, incondicionado e desregrado às praias da região não poderá se dar sem que implique no pagamento de um preço: o aniquilamento do plexo ambiental ali ainda existente. Não será possível canalizar alguns milhares de veranistas a uma área de proteção ambiental sem que o tênue equilíbrio ecológico ali verificado se altere. Desta alteração decorrerá, cedo ou tarde, o perecimento do meio-ambiente.

Se admitirmos como válida a assertiva anterior - e a história recente do local onde se situam diversas praias - entre as quais a referenciada é testemunha da sua veracidade ou, no mínimo, de sua plausibilidade - chegamos ao núcleo da polêmica. Esta se situa na necessidade de conciliação entre o direito constitucional ao desfrute equânime do que é público, confrontado com a proteção e preservação ambiental, também de albergue na Carta maior. E nesta zona lindeira entre pautas e princípios constitucionais que, imaginamos, devemos caminhar. para que se encontre um ponto de equilíbrio permitidor da conciliação entre os valores e bens jurídicos envolvidos. É o que tentamos fazer aqui.

Antes de desfiar as razões e fundamentos jurídicos que entendemos cabentes ao caso, cumpre uma necessária ressalva. Não pretendemos aqui assumir uma posição imparcial e neutra quanto à questão ${ }^{2}$. Não escamoteamos nossa posição enquanto patronos da associação de defesa dos interesses dos proprietários dos lotes lindeiros à praia. Impossível que é a imparcialidade, intentamos, contudo, manter com relação aos temas enfocados uma certa objetividade. E fazemos a ressalva apenas para que as razões aqui apresentadas sejam avaliadas pelos seus próprios fundamentos e não por serem vazadas por autoridade ou por uma olímpica opinião legal.

Ao nosso ver, a explicitação do ângulo desde o qual enfocamos a questão objeto do presente não pode invalidar o substrato jurídico do seu desate. Ainda mais quando a matéria versada envolve valores de abrangência tão ampla quanto o que se aqui cogita.

2 O que ademais em sede do discurso jurídico parece ser sempre impossível. A este respeito, Cf. Alícia E. C. RUIZ, "Aspectos Ideológicos del Discurso Jurílicu", in "Materiales para Una Teoria Critica del Derecho". Buenos Aires, Abeledo-Perrot, 1991, pígs. 149 a 188. Ver também, Eros Roberto GRAU, "O Direino Posto e o Direito Pressulposto". São Paulo. Malheiros, 1996, pág. 115 : "Assim os pensamentos näo são completamente livres, na modida cm que as ciências nem a prudência são neutras. " 
Antes de nos embrenharmos nas hipóteses práticas de equacionamento jurídico do impasse colocado, cumpre deitarmos alguma atenção a uma retlexão aridamente teórica, mas de enfrentamento necessário para desate do tema.

$\hat{E}$ que a questão aqui ventilada nos remete à discussão em torno du que se convencionou chamar de oposição entre princípios. De um lado a isonomia e a universalidade no desfrute do patrimônio público. De outro a preservação do meio ambiente. Longe de querer aprofundar tema tão tortuoso, tomemos a liberdade de tecer algumas palavras acerca deste ponto.

Celso Antônio Bandeira de Mello, analisando a questão dos princípios no campo do direito administrativo, é peremptório ao afirmar que são os princípios que embasam, arrimam e dotam o sistema jurídico de espírito "servindo de critério para sua exata compreensão e inteligência, exatamente por definir a lógica é a racionalidade do sistema normativo, no que the confere a tônica e lhe dá sentido". É justamente esta função de conferir alguma racionalidade, algum "cimento lógico" ao conjunto de enunciados que integra um sistema jurídico que dá o caráter de imprescindibilidade aos princípios, estejam eles "positivados" ou nãot.

Portanto, se estes princípios - ou "bitolas" nas palavras de Claus-Whilhelm Canaris $^{5}$ - são essenciais para conferir um nexo, um amálgama de sistematicidade às regras (ou enunciados normativos) que compōem um dado Ordenamento Jurídico, será imperativo analisar como os diversos princípios integrantes deste dado ordenamento se relacionam. Sim, porque na dinâmica do direito, não se pode pressupor que estes princípios nunca sejam confrontados uns com os outros. É. neste passo que se coloca a questão do conflito entre us princípios ${ }^{6}$.

A questão que se coloca. portanto. se prende aos critérios de seletividade para adotar um princípio em detrimento de outro. Ou melhor. aos critérios de escolha para compor os diversos princípios, dentro de um padrão de racionalidade ao mesmo

3 BANDEIRA DE MELLO, C. A.: "Curso de Dircito Administrutiv". fte ediçẫo Revista e Ampliadai. Editora RT, 1993, págs. 408 a 409.

4 A este respeito, vale referir a clara exposiçāo desenvolvida por Eros GRAU em sua lese de titularidade "A Ordem Econômica na Constituiçăo de 88 (interpretação e critica)". tese defendida em 1990 no concurso para a Cáteda de Direito Econômico na Lniversidade de São Paulo, mimeo, págs. 97 e segs.).

5 Atirma Claus-Whilhelm CANARIS que: "A exishência do Direito assenta nama série de fenômenos que se concretizam com regularidade. Sem essa regularidade, o Direito não teria qualquer consistência, ideal ou real: ininteligivel, imperceptivel e ineficas, ele deveria ser afastado das categorias existentes". E continua: "Em termos esquemáticos, pode considerar-se que, mediante bitolas eleitas em cada culura jurílica, o Direito tende a tratar o igual de modo igual e o diferente de modo diferente, de acordo com a medida da diferença. De outro modo, os diversios problemas concretos seriam resolvidos ao acaso. surgindo como expressás do puro arbitrio. "in CANARIS, Claus-Whilhelm: "Pensamento Sistemático e Conceito de Sistema na Ciência do Direito". Lisboa, Fundação Caloste Gulbenkian, 1989, páig. LXIII.

6 Acerca do tema ver nosso "O conflito entre princípios constiucionais: Breves pautas para sua soluçäo". in "Cadernos de Direito Constitucional de Ciência Política", volume 10, pág. 40. 
tempo condizente com o sistema jurídico e funcional para o processo de aplicação do Direito.

As regras (ou normas) jurídicas não surgem do nada. Ao menos no direito moderno, não são reveladas. São, isto sim, fruto do contínuo processo de elaboração consciente e racional dos indivíduos integrados no e pelo sistema jurídico. E esta construção se opera mediante consensos, os quais são sempre lastreados em princípios. O processo de aplicação ou de interpretação deste ordenamento será sempre conflitivo e se dará a partir da valorização de alguns princípios em detrimento de outros?.

Como nos ensina J. J. Gomes Canotilho: "no caso de conflito entre princípios, estes podem sempre ser objeto de ponderação, de harmonização, pois eles contêm apenas exigências ou standarts que prima facie devem ser realizados". Dito de outro modo: "a convivência de princípios é sempre conflitual."

Esta seleção de princípios - explícita ou implícita - não vai se pautar por critérios formais como ocorre no conflito de normas (critério temporal, critério de especificidade, critério de competência da autoridade etc.).

Não. Em sede de princípios a seleção se dará sempre a partir de critérios de conteúdo, guiados pelo critério de racionalidade adotado no caso específico.

Não é por outro motivo que autores como Robert Alexy nos falam de resolução dos conflitos entre princípios pelo critério do peso."

O peso diferencial entre os princípios a que alude Alexy (cf. nota supra) não se configura em si. Depende do contexto em que um dado princípio é invocado. Ou seja: a densidade que faz um princípio jurídico prevalecer em relação a outro não pode ser tomada como definitiva, restando eminentemente conjuntural ${ }^{10}$.

Diante disto, podemos - e devemos - voltar à questão concreta que toma nossa atenção, pois, vimos, a oposição entre princípios deverá ser sempre superada levando em conta as peculiaridades do caso concreto. In casu, e estritamente nos seus marcos, cremos que o peso diferencial da proteção ambiental é infinitamente mais denso que o uso irrestrito de bem público travestido na impossibilidade de se limitar o acesso dos eventuais banhistas às áreas praianas.

7 Daí porque alguns autores, como salienta Canotitho, definirem hodiernamente a Constituição como sendo "um estatuto reflexivo que, através de certos procedimentos, do apelo a auto regulamentaçōes, de sugestōes no sentido da evolução político-social. permite a existência de uma pluralidade de opçōes políticas, a compatibilização dos dissenssos, a possibilidade de vários jogos políticos, a garantia da mudança através da construção de rupturas", in "Direiro Constitucional", $5^{\mathbf{a}}$ edição, Coimbra, Alınedina, 1990, pág. 14. Para um aprofundamento da idéia de direito autoreflexivo ver Gunter TEUBNER, "Rechsts als Auyopoienisches System".

8 J.J. GOMES CANOTILHO. op. cit., pág. 174 (grifos do autor).

9 Robert ALEXY, in "Theorie der Grundrech", píg. 76, apud Erus Grau, op. cit., pág. 116.

10 Vai daí que a atividade de interpretação do direito é ao mesmo tempo contextual e dinâmica, tendo como limites fundamentais a sua compatibilidade e adequação a um padrão de racionalidade compatível com o sistema jurídico. 
E sustentamos isto por vários motivos. Pela amplitude dos direitos afetados. Pela densidade conferida na Constituição à preservação ambiental. Pela relevância dos bens jurídicos tutelados. E. por fim. pela insuprimibilidade da preservação ambiental en confronto com a relativa disponibilidade da limitação do acesso às praias em apreço.

Em primeiro lugar. a proteção do meio ambiente á algo yue pertine a toda a humanidade. Não se restringe, nem pela nacionalidade. nem pelo interesse nem mesmo pelo fato de se estar ou não vivo (o meio ambiente é bem tutelável para ats presentes e futuras gerações). Já o uso do bem público praia tange àqueles que têm meios para acessar o balneário e que, os tendo, se interessian por este tipo de lazer. A diferença de amplitude se aprofunda quando pensamos no acesso motorizado, o qual, por óbvio, só pode ser pertinente àqueles que têm acesso a um veículo automotor. Um bem jurídico (proteção ao meio ambiente), portanto, tem abrangência muito mais ampla do que outro (acesso irrestrito ao bem de todos - praia).

É inegável que a Constituição elevou à condiçẫo de princípio de altaı relevância a preservação ambiental. Não fosse pelo fitto de que a Carta de 88 "define o meio ambiente ecologicamente equilibrado como direito de todos e the da natureza de bem de uso comum do povo" ", mas também e principalmente porque "na verdade o faz para assegurar o direito fundamental à vida"'?2. E o direito à vida, contemplado no art. $5^{\circ}$, caput, da CR é basilar. essencial, prevalecente em relaçíio a todo e qualquer outro princípio ou valor contemplado na ordem jurídica. ${ }^{1.3}$

De outro lado, o texto constitucional dedica relevância impar à tutela do meio ambiente. Tanto é assim, que a ele reservou capítulo específico (Capítulo VI) ${ }^{14}$. Atribuiu competência para a proteção do interesse ambiental tanto ao autor popular (artigo $5^{\circ}$, LXXIII) quanto especificamente ao Ministério Público (artigo 129. III); deu contornos de crime passível das sanções penais às condutas lesivals au meio ambiente (artigo $225, \S 3^{\circ}$ ). Não contente, imputou o dever de defesa e preservação não só ao poder público - de forma concorrente entre todos os entes da federação (artigo 23, VI) - como também à coletividade (artigo 225, caput).

Por fim, há a desigualdade entre o acessso irrestrito a algumas praias e a proteção do meio ambiente sob o prisma da reparabilidade. Uma vez destruído um ecossistema, não se compensa ou restitui a humanidade. Já quando disciplinado o uso de um bem público, há meios de se reduzir o cerceamento que ele implica. Por um lado, através do uso regulamentado ou monitorado a tal bem (como ocorre com os Parques

11 José Afonso DA SILVA, "Curso de Direito Constitucional", São Paulo, RT. 7a edição, 1990, pág. 708.

12 José Afonso DA SILVA. "Direito à qualidade do meio ambiente". in "Revista do Advogado", volume 18, junho de 1985. pág. 46.

13 Como perora Jacques ROBERT, "O respeito à vida humana é a am tempo uma das maiores idéias de nossa civilização e o primeiro principio da moral médica." Jacques Robert. in "Libertés Publiques", Editora Montchrétien, píg. 234.

14 Igualmente o fez o constituinte estadual paulista, que abriu o capítulo IV para a matéria ambiental, recursos hídricos e saneamento e dedicou, dentro dele, seçĩo específica para o Meio Ambiente (Seçĩo I). 
Nacionais ou com as Reservas Ecológicas). De outro, com políticas de desenvolvimento de formas alternativals de uso ou de lazer, na área ou no entorno.

Acrescente-se a isto o fato de que as áreas de proteção ambiental envolvida (Mata Atlântica e Serra do Mar) são elevadas à condiçáo de bem de uso comum do povo pela própria Constituição (artigo $225 . \$ 4^{\circ}$ ), as quais deverão ter sua utilização regulamentada de modo a permitir, como pressuposto relevantíssimo até por tautologia, a sua preservação.

Portanto, parece-nos inafastável a exegese de que o princípio da universalidade do bem público - de inegável assento constitucional - não poderá se manifestar, na vida prática, de forma a colidir com a própria pauta ditada pela Constituição para uso e desfrute deste determinado bem. Se a Carta maiur impõe que um bem público específico seja utilizado de forma consentânea com a preservação ambiental, não se pode apregoar, com lastro na própria Constituição, o uso irrestrito que põe em risco o próprio bem. Interpretação em sentido contrário seria, concessa venia, afrontar o bom senso e as regras da hermenêutica.

Situado que, diante da oposição dos princípios constitucionais nomeados supra, deve prevalecer, no casso, a preservação ambiental, restaria enfocar os mecanismos que lobrigamos para viabilizar tal harmonização. E au nosso ver, estes mecanismos são encontradiços tanto nos institutos do direto público, quatnto nas próprias normas insertas na Lei Orgânica do Município envolvido.

Duas são as alternativas que vislumbramos: a) a restrição to tráfego e ao acesso imposta pelo poder público no exercício do seu poder de polícia; b) a outorga de uso privativo de bem público mediante condição de preservação ambiental. Desenvolveremos, na sequiência. us aspectos jurídicos enredados nas duas alternativas.

\section{A inexistência de privilégio de interessés privados na restriçāo}

Não podemos fazê-lo sem antes enfocar uma última preliminar. Transpira de toda a discussão envolvida na presente matéria um certo viés ideológico pelo qual qualquer empecilho ao acesso irrestrito de turistas à área implicaria num odioso privilégio dos proprietários de imóveis. Em outras palavras: a restrição ao acesso padeceria de inconstitucionalidade a priori, pelo simples fato de consagrar interesse privado - dos que lá possuem lotes — em detrimento do interesse público — dos que querem ir àquela praia.

Esperamos já ter demonstrado que a obrigar a restrição há um interesse público mais denso e mais amplo (pois que plena e absolutamente difuso, pertinente a todo indivíduo existente e por vir à face da terra). Contudo, a ojeriza refletida no vezo que assume o debate trai também uma certa concepção ideológica que compreende o interesse público como sendo sempre diverso do interesse privado ${ }^{15}$. Por este viés

15 Bom exemplo dessa concepção clíssica do interesse público em oposição alo interesse privado, pode ser obtido no Direito Penal. O artigo 321 do Código Penal (reflexo da visão que se tinha da Administração Pública nos idos de 1940) cuida de apenamento que revela falsa oposição entre 
a única hipótese de se afirmar o interesse público seria por sobre e por contal du interesse privado 16 .

Nas sociedades contemporâneas, contudo, não mais se permite tão absoluta dicotomia ${ }^{17}$. Crescentemente, assistimos a emergência de espaços em que o interesse público se confunde com o interesse dos particulares ${ }^{\text {ls }}$. Esta interpenetração entre as esteras do público e do privado é hoje de tal monta que passa a ser quase impossível manter a concepção de oposição cabal entre interesse público e privado. passando-se a trabalhar com a noção de coatividade. de cooperaçãol".

Assim, não nos parece possível se rejeitar mecanismos de consagração do interesse público só pela circunstância de, num dado contexto, uma medida de ordem pública venha a coincidir com um interesse de particulares. Afinal, muita ve simples consumação de um legítimo interesse privado será via de consagração do interesse público. Em suma há que se considerar hoje que um interesse legítimo,

interesse público e privado. pois que torna apenável a conduta de servidor que simplesmente respalda ou encaminha perante a Administraçāo legítimo interesse de particular. E. como diverso não poderia ser, tal tipificição reflete uma concep̧̧ăo de Estado, de Administração que como dissemos. vem sendo paulatinamente superada. Em suma, subjas aquele tipo penal uma oposição frontal entre o interesse público e o privado. como se tais interesses jamais pudessem ser coincidentes. Em poucas palavras, a prática da advociacia administrattiva deve hoje a nosso ver sempre ser verifiada tendo em vista o interesse especial do servidor em atender ou farter atender a um interesic privado específico, sem razĩo de ordem pública a ensejá-lo ou em detrimento do interesse de outros particulares.

16 Ver Alberto AMARAL JÚNIOR, "Proteşa do Comsumidor no Contrano de Compra e Venda". Editora RT, 1993, págs. 77 e segss. Ver também José Eduardo Faria, "Diréito de Eionumia na Democratização Brasileira". Sảo Paulo. Malheiros, 1993. púgs. 79 a 82.

17 Dentro do Direito Administrativo pátrio. entendimento da mesma forma atual é esposido por Odete Medauar que assevera: "Além dessa indeterminação a priori do interesse páblico. outros fatores acarretaran modificaçöes na trangiäla dualidade interesse píblico interesse privado e na homogeneidade do primeiro. Deve-se lembrar o dado das atuaçòes de paricularess consideradas

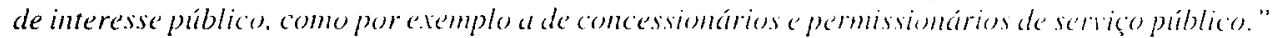
(cf. "O Direilo Administrative èm Evolıç̧ōo". pág. 181).

18 Em outra passagem. a retro citada professora titular do Largo de São Francisco alssegura: "A uma concepção de homogeneidade de interesse público segue-se. assim, uma situaçăo de heterogeneidade: de uma idéia de unicidade passoutse à concreta existência de mulliplicidade de interesses publicos. f dourrina contemporânea refere-se à impossibilidade de rigides na prefinação do interesse público, sobretudo pela relatividade de lodo padräo de comparação." (op. cit.. loc. cit.)

19 Este processo é percebido argutamente por Norberto Bobbio. que em outro célebre trabalho leciona: "De fato. o processo de publicização do privado é apenas ama das faces do processo de transformação das sociedades industriais mais avançadas. Ele é acompanhado e complicado por

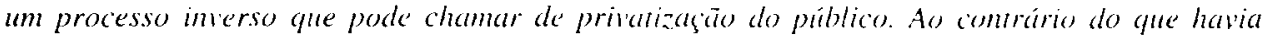
proposto Hegel, segundo o qual o Estado como totalidade ática terminaria por so impor à fragmentaçäo da sociedade civil, interpretada como 'sistema da atomistica', as relaçóes de tipo contratual, características do mundo das relações privadas, näo foram reatmente relegadas à esfera anterior das relaçôes entre individuos e grupos menurés. mas reemergiram à fase superior das relaçōes politicamente relevantes ..." Norberto Bobbio, in "Estado. Gorerno, Sociedade". São Paulo, Editora Paz e Terra. $3^{3}$ ediçăo, 1990, pág. 26. 
mediato ou imediato. de um particular nào pode significar automaticamente um interesse contrário aos desígnios públicos. E nessa bitola. desvestido de todo e qualquer preconceito, que se deve evocar as soluções cogitadas.

$\mathrm{O}$ interesse dos proprietários de lotes é irrelevante em relação ao interesse público maior residente na proteção ambiental. O fato desses interesses privados serem contemplados serve para invalidar medidas que visem à proreção de interesse público mais relevante. Não atender este apenas porque beneficiaria aqueles seria afrontar a própria razoabilidade intrínseca à urdem jurídical.

A ninguém é dado desconhecer que a atividade administrativa, muita vez, acaba por atender interesses privados. Assim é em diversos exemplos tomados ao aciaso.

Quando, na realização da atividade fomentadora, a Administraçĩo pública estabelece algum incentivo fiscal ou alguma proteção tarifária. está obviamente a favorecer os atores privados envolvidos neste setor empresarial favorecido. Isto apenas não implica em beneficiamento ou em iniquidade qualquer. Tal procedimento é plenamente legítimo desde que o ato da Administração tenha motivação embasada em interesse público transcendente (proteção da indústria nacional. preservação de postos de trabalho, criação de tecnologia própria etc.).

Da mesma forma. quando o poder público expropria inóvel rural para nele assentar número determinado de famplias, é óbvio que estes agricultores são diretatmente beneficiados pela medida. Ninguém. ao menos fora do discurso político ideológico, cogitaria de obstar a política de reforma agrária sustentando que ela caracteriza odioso tratamento desigual dos assentados em detrimento dos outros sem terra ainda acampados à margem das estradas.

Um último exemplo. Quando o poder público tomba uma área X, determinando que seja ela preservada ou quando dá a uma determinada área verde a destinação de um parque público, certo é que os possuidores de imóveis vizinhos são agraciados com um benefício impar. Ao invés de terem nat suas vizinhanças um empreendimento imobiliário. passam a ter no seu entorno uma aprazivel área preservada, um jardim ou uma praça.

Nem por isso o ato de criação desta suposta área verde está maculado de vício. Se uma valorização adveio para os proprietários de imóveis lindeiros, há instrumentos tributários (p.e. a Contribuição de Melhoria) ou urbanísticos (imposição de ônus adicionais ao exercício da propriedade nos imóveis lindeiros). Contudo, a ninguém ocorreria tentar anular a criação da área preservada só porque alguns afortunados passariam a ser vizinhos de um parque.

Dizemos tudo isto para deixar bem fixado que o simples fato da atividade administrativa acarretar benefícios e proveitos indirelos extensivos a apenas alguns administrados, não torna inquinados de nulidade nem faz imorais os atos do poder público. Afinal, como a atividade da Administração Pública não se realiza estanquemente, se desdobrando dentro do mundo da vida, os seus reflexos atingem diferentemente os administrados.

O que importa é saber se os atos tomados vão ou não ao encontro de interesses públicos (finalidades públicas) como já ensinou o saudoso Cinne Lima ${ }^{20}$. Se há um 
lastro de finalidade públical a ensejá-lo. o ato é legal e legítimo, beneficie ou não, indiretamente, algum administrado. seja ele mais ou menos aquinhoado pela virtude ou pela fortuna. No casso em tela, há. é inegável. motivos suficientes de ordem pública a determinar a restrição do acesso - ao menos do trátego - à regiào. Portanto, deve ser afastado qualquer viés desligitimador das medidals que ora se sugere.

\section{A hipótese de restrição imposta pela administração no exercicio de poder de polícia $^{21}$}

Como já ensinava a mais antiga doutrina entre nós, "o condicionamento dos direitos individuais tendo em vista o bem comum säo feitos pelo Estado no exercicio do seu chamado poder da polícia de supremacia." 22 . Na verdade, não deve restar dúvidas que da atividade administrativa - consubstanciada en atos administrativos - pode advir a interferencia restritiva na esfera dos direitos dos administrados.

21 É longuíssimat a bibliografia sobre o tema. Apends como apontamentos gerass, colhidos alhures nas estantes e sem pretensio de rol exanstivo, alinhe-se: Adolfo MERKL. Téria general del derecho administratio. Madrid. 1993. págs. 323: Alberto ELGLERA. Policia manicipal. Buenos Aires, 1963: Alberto DOMÍNGUEZ. Polícia sanitaria, Buenos Aires, 1940, etc. En la bibliografia general pueden verse Dicz. Manuel María. Derecho Administrativo. tomo IV. Buenos Aires, 1969. págs. 17 y segs.: Álvaro LAZZARINI c outros. Dircio Administratio da Ordem Pública; Bartolome FIORINI, Manual de Derecho Administrativo, volume II. págs. 645 e segs.: Bartolome FIORINI. Poder de Policia. Buenos Aires. 1962: Celso Antunio Banderit de MELLO. Elementes de Dircito Administraivo págs. 240 e segss.: Clóvis BEZNOS. Poder de Policia: Diógenes GASPARINI. Dircilo Admintstrative, púgs. 98 e segs.: Diogo de Figuciredo MOREIRA NETU, Curso de Direito Administrutio,o, púgs. 293 e segs.: Fernando Garrido FALLA. Tratado de Derecho Administrativo, volume II. págs. 159 e segss: Francis-Paul BÉNOIT. Le Droil Administratif Francais, págs. 739 e segss: Goorges VEDEL, Droit Administratif, págs. 779 e segs.; H.L.LAFERRIÈRE. Cours de Droil Public e Administratif. Volume I, pígs. 368 e segs.: Gurmán J. Bidart CAMPOS, Derecho constiancional. tomo II. Buenos Aires. 1966. pägs. 550: Héctur Eduardo. HERralZ, Poder de Policia. Buenos Aires, 1970: Hely Lopes MEIRELLES. Direito Administrativo Brasileiro, págs. 113 e segs.: Henry BETHÉLEMY. Traité Éléméntaire de Droit Administratif. págs. 235 e segss.: Jcan RIVERO. Droit Administratit, págs. 450 e segs.: José CRETELLA Jr., Cur.so de Direito Administrativo, págs. 521 e segs.: Manuel Maria DIEZ. Derecho Administratio. volume IV. págs. 17 e segs.: Miguel S. MARIENHOFF. Tratade de derecho administrativo tomo IV. Buenos Aires, 1973. págs. 510 e segs sosé Horicio Meirelles TEIXEIRA. Estudos de Direito Administrativo, volume I, págs. 153 e segs.: Juan Francisco LINARES, Derecho Administrativo, págs. 421 e segs.: Marcel WALINE. Mantel Élémentaire de Droil Administratif, págs. 240 e segs.: Néstor R. VALERI, Implicancias constitucionales del instituto de policia. Sinta Fe, 1961: Otto MAYER. Derecho Administrative Alemán. volume II. piigs. 3 e segs.: Pedro Guilhermo ALTAMIRA. Policia y poder de poticia, Buenos Aires. 1463: Ralial BIELSA, Régimen de polícia, Buenos Aires. 1957: Ramón F. V'ASQUEZ. Poder de policia, Buenos Aires, 1957: Roger BONARD. Précis Elémentuire de Droit Administranif. págs. 397 e segs.: Renato ALESSI, Sistema lstiturionale del Diritu Amministrativo laaliano. págs. 461 e segs.: Themístocles Brandio CAVALCANTI. Curso de Dircion Administraliow. págs. 115 e segs.

22 Oswaldo Aranha BANDEIRA DE MELLO. "Principios (icrais de Dircilo Administratio". Rio de Janeiro. Forense. 1969. Volume I1. págs. 27. 
produzindo sobre eles "obrigaçöes, deveres, cargas antes inexistemles, ou restrições, limitações ou extinções de titularidades atrivas prévias." 23

A atividade de polícia é, talvez, aquela yue mais se faz presente na vida dos administrados. Ela se revela na imposição de fïscalização periódica de elevadores. na físcalização realizada pela vigilância sanitária junto às casas de pasto, na exigência de alvará e de cumprimento das normas edilícias, na imposição de norinas de tráfego e trânsito, na ordenação urbanística, e em outros inúmeros setores ${ }^{24}$. Ademais, a polícia administrativa se manifesta de diferentes formas, quer por intermédio de atos normativos de caráter geral (p.e. portaria que regula a venda e o uso de fogos de artifício em épocas juninas), quer por injunçôes concretas (v.g. fechamento de estabelecimento aberto sem licença ou fora das normas de zoneamento $)^{25}$.

Assim sendo, pode-se conceituar o poder de polícia como sendo "a atividade administrativa que se caracterizaria por ser ama atividade de limitaçäo de direitos dos cidadäos, com o objetivo de prevenir os perigos que do seu livre excricio poderiam derivar-se para a coletividade" 20 .

Embora sendo uma área da Administração presente desde tempo imemoriais - e até talvez por isto - a concepção de poder de polícia suscita inúmeras imprecisões, dúvidas e controvérsias. A tal ponto que doutrinadores de escol propugnam pela eliminação da própria idéia de poder de polícia ${ }^{27}$, enquanto outros, com brilho também destacado, defendem a reformulação da vetusta noção. que deveria dar lugar a fórmulas da "Administração Ordenadora" 28.

Se o tema suscita controvérsias entre os iniciados, entre us leigus cria contusōes enormes. Destas talvez a maior seja o renitente baralhamento entre a) polícia administrativa, b) polícia judiciária e c) pulícia de manutenção da ordem pública. O fato é que quando fazemos referência ao poder de polícia. aos não iniciados ocorre sempre a imagem do policial militar ou do delegado de polícia. Como o tema tangência o ora enfocado, cumpre aclarar a confusão.

É Hely Lopes Meirelles quem nos socorre neste intento, demonstrando que "a polícia administrativa incide sobre os bens. direitos e atividades, ao passo que as outras atuam sobre as pessoas individualmente ou indiscriminadamente. A policia administrativa é inerente e se difunde por toda a Administraçäo Päblica. enquanto

23 Eduardo Garcia de ENTERRÍA e Tomás-Ramón FERNANDEZ. "Curso de Direitu Administrativo", São Paulo. Editora RT, 1990, pág. 822.

24 Ct. neste sentido Diógenes GASPARINI, "Direito Administratiro", São Paulo, Saraiva, 1992, pág. 118.

25 A classiticação e os exemplos são emprestados de Celso Antônio BANDEIRA DE MELLO, "Curso de Direito Administratiso", 8" edição, pág. 493.

26 Eduardo Garciat de ENTERRÍA e Tomás-Ramón FERNANDEZ, cit., pág. 822.

27 De recomendável leitura sĩo as convincentes págs. tecidas por Augustin GORDILLO na defesa deste ponto de vista (cf. "Tratado de Derecho Administrativo". Buenos Aires. Ediciones Macchi, Tomo 2, págs. XII.12 a XII. 16.). Adere entré nós à crítiça do ildninistrativista alemão Celso Antônio BANDEIRA DE MELLO. "Curso ...", cit.. pág. 485.

28 Ver Carlos Ari SUNDFELD. "Direito Administrativo Ordenador". Sĩo Paulo. Malheirus. 1993. 
que as demais são privativas de determinados órgäos (polícias civis) ou corporações (policias militares)" ${ }^{21}$ O que nos importa aqui é distinguir o poder de polícia genérico, que reside na Administração pública como um todo, do poder de polícia específico ${ }^{30}$ cujo exercício compete constitucionalmente a órgãos determinados da Administraçâo e que recaem. fundamentalmente, sobre a liberdade do individuo a partir, principalmente, do ponto de inflexão do ilícito penal ${ }^{31}$.

Em suma. quando aqui cogitamos de restrições ao acesso à área em questào levadas a cabo pelo Poder Público no exercício do seu poder de polícia, não estamos aludindo à presença de policiais militares ou civis com atribuição pară deter indivíduos ou impor sua alutoridade pelo monopólio da coição físicat. Estamus nus referindo à prerrogativa da Administração para impor limitaçôes impostats pela Administração pública voltadas a "condicionar, com fiundamento cem sua supremacia geral e" ha forma da lei. a liberdade e a propriedade dos individuos, mediante aşäo ora fiscia-

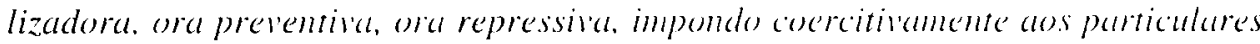
um dever de abstençäo ("non facere") a fim de conformar-lhes os comportumentos aos interesses sociais consagrados no sistema normativo." 32.

Pois bem. sobre estas notas doutrinárias é que repousa a primeira alternativa sugerida por nós para desate da questão trazida. Na prática, teríamos a imposição pelo Poder Público municipal de restrições (parciais ou totais) a trátego na região, restriçôes estas que poderiam chegar à proibiçio de circulação de veículos automotores a partir de um determinado ponto do viário. Exceção poderia ser feita aos que possuem imóveis no loteamento, pois que esta seria a única forma de acesso às suas propriedades.

A causa - ou seja, o elemento de necessidide que, segundo Maria Sylvia Zanella DI PIETRO 33 , constitui requisito essencial para legitimar o exercício do poder de polícia - para tal restrição é suficiente e legítima. A adoção de tal medida, como já demonstramos, é ditada pela ameaça real existente no acesso irrestrito de veículos ao local. Tal acesso poderá acarretar tanto o irreparável dano ao meio ambiente como pôr em risco a segurança dos indivíduos (pois que o viário não comporta tráfego intenso), além de comprometer a integridade de bem público (pois as condições geológicas fazem com que as ruas cedam se submetidas à tráfego intenso). Lastro fático motivacional, portanto, haveria para tais medidas.

Já quanto ao lastro jurídico para tais medidas, há também fárturä.

29 "O Poder de Policia, o Desemvolvimento e a Segurança Nacional", in RDA, volume 125, julho a setembro de 1976, págs. 02 .

$30 \mathrm{O}$ qual por seu turno compreenderia a polícia repressiva e a polícia judiciária. A diferenciação entre as duas refoge em muito dals nossals preocupações por ora. Para um aprofundamento ver Álvaro LAZZARINI. "Limites do Poder de Policia", BDA - Boletim de Direito Administrativo. volume 11/96, nuvembro de 1996, págs. 728 a 730.

31 Neste sentido. Álvaro LAZZARINI. RTJSP, volume 98, pígs. 20 a 25.

32 Celso Antônio BANDEIRA DE MELLO, "Aponamentess sobre o Poder de Policia". RDP --. Revista de Direito Público, Editora RT. volume 09. pígs. 62.

33 Ct. "Direito Administrativoo", Sũo Paulo. Editorat Atlas, fa edição. píg. Io(). 
O Código Tributário Nacional contempla no seu artigo 78 o exercício do poder de polícia pelo poder público definindo-o como "a atividade da administração pública que, limitando ou disciplinando direito, interesse ou liberdade, regula a prática de ato ou a abstenção de fato, em razão de interesse público concernente à segurança, à higiene à ordem, aos costumes, à disciplina de proteção do mercado, ao exercicio de atividades economicus dependentes de concessão ou autorização do Poder Público, à tranqüilidade pública ou ao respeito à propriedade e aos direitos individuais ou coletivos." Estando patente o envolvimento do interesse difuso de proteção ambiental, parece ter guarida na regra do CTN a atividade limitadora ou restritiva do direito de uso dos bens públicos, do direito (ou interesse) de acesso motorizado à praia ou mesmo de uma suposta liberdade de ir e vir mediante ato emanado no âmbito do poder de polícia.

Por outro lado, a bem elaborada Lei Orgânica do Município interessado é pródiga em outorgar ao Município competência e em lhe atribuir função para adotar tais providências. No diploma vêm insculpidas as competências do Município no exercício de sua autonomia, estabelecendo, além da previsão genérica e constitucional de prover a tudo quanto respeite ato interesse local. as segs. atribuições: i) dispor sobre administração, utilização e alienação de seus bens; ii) regulamentar a utilização dos logradouros públicos; iii) fíxar e sinalizar os locais de estacionamento de veículos, os limites das "zonas de silêncio" e de trânsito e tráfego em condições especiais; iv) sinalizar as vias urbanas e as estradats municipais, bem como regulamentar sua utilização; v) promover a proteção do patrimônio histórico, cultural e turístico local, observada a ação fiscalizadora federal e estadual: vi) fazer cessar no exercício do poder de polícia administrativa, as atividades que violarem as normas de saúde, higiene, sossego. segurança, funcionalidade, moralidade e outras de interesse da coletividade.

Se é verdade que a LOM outorga competência para a Municipalidade agir no condicionamento do uso dos bens públicos e na restrição das liberdades dos indivíduos, não menos verdadeiro é que a constituiçĩo municipal impõe ao poder público assim agir visando à preservação ambiental. A Lei Orgânica prescreve que ao Município compete a atribuição de, concorrentemente às outras esferas da Administração, i) proteger o meio ambiente e combater a poluição em qualquer de suas formas; bem como de ii) preservar as florestas, a fauna e a flora.

Propugna, também, como princípio da atividade do Município a defesa do meio ambiente. E, antes de consagrar um capítulo todo à proteção ambienta. assegura como meta da política urbana municipal i) a preservação. proteção e a recuperação do meio ambiente urbano e cultural e ii) a criação e a manutenção de áreas de especial interesse histórico, urbanístico, ambiental, turístico e de utilização pública.

Parece-nos, portanto, que a Lei Orgânica do Município interessado praticamente impõe ao município a adoção das providência de que ora se cogita, oferecendo ampla e explícita autorização para o exercício do seu poder de polícia neste mister. Como, apesar da previsão legal, sempre haverá, em sede do polêmico tema, quem aponte obstáculos a limitar a ação do poder público em situações semelhantes, permitimonos abordar alguns dos argumentos que podemos, desde logo, antever. 
Poder-se-ia dizer, contra a hipótese em cogitação. não ser possível por ato decorrente de poder de polícia impor tal restriçĩo ao uso de bem público. A confrontação, porém. não procede. Assistimos, diuturnamente. manifestações de polícia da espécie. Toda a atividade de regulamentação de trátego e trânsito envolve. de uma forma ou de outra. restrição no uso que o individuo queira dar au viário. Não podemos eu invocar o fato da rua ser bem público de uso comum para estacionar onde a parada é proibida ou onde para trafegar contra a mão de direção. Não pode o transportador de cargas aludir a universalidade do uso das ruas de regiño central de uma metrópole para transitar com seu caminhão fora dos horários permitidos. Mais ainda. não é facultado ao morador invocar a publicidade das pistas de uma rodovia para impedir que o poder público, em certos horários e ocasiões, as feche no sentido ascendente. . $^{3.4}$.

Tampouco prospera a alegação de que estes condicionamentos não poderiam chegar ao impedimento do tráfego em via pública. O exemplo dos caminhões em áreas de movimento intenso ou a imposição de rodízio de veículos na cidade de São Paulo (medidas que. aliás. têm por fulcro o combate à poluição) já demonstram a fragilidade do argumento. Contudo, há exemplo mais contundente. É comum - e ao que se saiba isto nunca suscitou batalhas jurídicas - o estabelecimento pelas Prefeituras das ditas zonas de calçadäo, ou sejal, o fechamento de vias antes entregues ao tráfego de veículos automotores para que nelas apenas transitem pedestres. Trata-se de medida típica de poder de polícia (inserida dentro das manifestações de controle e regulamentação do tráfego), com vistas ao atingimento de diretrizes urbanísticas e que, em última análise, leva a uma restrição do uso do bem público (rua) aos automóveis.

O exemplo serve também para afastar outra crítica possível. Dir-se-ia que. uma vez restrito o tráfego de automóveis nas vias que serpenteiam pela encosta do morro que dá acesso à praia, não seria possível abrir exceção parră o tráfego dos que lá possuem casas. Não é verdade.

Ninguém sustentaria ser ilegal que o morador de um edifício de apartamentos trafegue pela calçada lindeira ao seu edifício como forma de acessar sua garagem subterrânea. E, sabe-se de há muito. que as calçadas são bens públicos de uso comum com vedação de rolamento ou parada de automóveis. O mesmo ocorre com os proprietários de apartamentos nas já citadas áreas de calçadão, aos quais é fornecida uma autorização especial de circulação para que atinjam as garagens de seus imóveis.

O que ocorre aqui é que a imposição de restriçóes decorrentes do poder de polícia deve estar adstrita também pelo parâmetro da proporcionalidade, que Maria

34 Com relação ao tema do fechamento de estradas em períudos de anormal fluxo de veículos, já se manifestou o E. TJSP dando guarida à tese aqui sustentada. Em Apelação interposta por possuidores de imóveis com testada para a Rodovia dos Imigrantes discutia-se a legalidade do fechamento de vias de acesso à roduvia. Embora a matéria seja ligeiramente diversá, cabe trazer à colação a ementa do aresto: "A legitimidade do poder de polícia em matéria de regulamentação do tráfego decorre da necessidade de atender aos interesses da colevividade. ligados à segurança. à trangiailidade, sossego e facilidade de transpone de loda natureza." (c). RDP, volumes 47 e 48. págs. 188 e segs.). 
Sylvia Z. Di Pietro formula como sendo "a exigência de uma relação necessária entre a limitaçăo ao direito individual e ao prejuizo a ser evizado" ${ }^{35}$. Se o tráfego do reduzido número de veículos de propriedade dos moradores não compromete o meio ambiente, seria um exagero. uma exorbitância, tolhê-los no seu direto de propriedade (impedindo que cheguem com seus pertences em suas casas) apenas por conta de uma inusitada "repartição uniforme dos ônus".

Mais uma vez é importante que se diga que a atividade administrativa implica sempre em benefícios ou sacrifícios desiguais aos administrados, porquanto quase nunca é possível distribuir igualmente as consequeencias das medidas e das políticas públicas. O relevante é que o fator de discrímem da atividade da Administração não advenha de fatores subjetivos mas sim de situações objetivas. hipótese que se verifica no caso vertente. ${ }^{36}$

Outra crítica que se poderia fazer diz respeito à suposta incompetência do Município para exercer poder de polícia afeto à matéria de trânsito, por desbordamento da competência municipal. Tal vetusta posição já foi espancada tanto pela doutrina quanto pela jurisprudência. No seu clássico "Direito Municipal" Hely Lopes Meirelles ${ }^{37}$ sustentava que "a polícia administrativa municipal deve estender-se a todos os locais públicos ou particulares abertos à frequiência coletiva (...)" Dizia ainda que "nestes lugares, a Administração municipal dispõe de amplo poder de regulamentação, colimando (...) as demais condições convenientes ao bem-estar público."

No mesmo sentido é a posição adotada em nossos Tribunais. Em Acórdão da lavra do Des. Régis de Oliveira, o Tribunal de Justiça de São Paulo decidiu:

"A previsão de infrações de trânsito encontram-se no CNT e tem força vinculativa a todo o território nacional, por nacional ser a lei. Mas no que diz respeito à circulação e estacionamento nos bens públicos municipais, tal como definidos em lei e que não diga respeito à circulação em vias públicas, a competência é toda do Municipio e exclui qualquer outra."

Portanto, a competência legislativa nacional para matéria de trânsito não é argumento para impedir que a Municipalidade exerça seu poder de polícia sobre os bens viários municipais, restringindo o tráfego de veículos na região afetada por proteção ambiental.

Outra questão que poderia ser levantada refere-se à possibilidade do poder de polícia municipal atingir - ainda que indiretamente - o acesso e uso das praias, bens públicos da União. Mais uma vez é a doutrina e a jurisprudência que nos socorrem para espancar também esta alegação.

35 Op. cit., paig. 100.

$36 \mathrm{Cf}$. Celso Antônio BANDEIRA DE MELLO, "Princípio da Isonomia: desequiparações proibidas e desequiparações permisidas". RTDP. volume 1, pägs. 81 e 82.

37 "Direito Municipal Brasileiro". São Paulo. Malheiros. 8" edição. atualizada. 1990, pág. 356.

38 Embargos Infringentes $n^{\circ} 163.721-1$. cf. LEX 144, págs. 200 a 205. 
Em irretorquível estudo a respeito do poder de polícia municipal sobre a zona costeira, Sérgio Sérvalo da Cunha liquida a questão: "As pratas marítimas, o mar territorial e os terrenos de marinha, embora sendo bens da União, localizam-se. não obstante. no território de algum município. Como parte deste território, incluem-se no âmbito da autonomia municipal e da respectira jurisdiçăo. (...) Aqui. o municipio exerce seu poder de policia como em qualquer outra cirea do seu território, disciplinando as edificaçôes o trânsito. (...) os bens e atividades do próprio Estado-membro e da União, existentes e desenvolvidas nessas áreas - à parte da imunidade tributária - sujeitam-se ao poder de policia local. conforme definido em lei". "3"

E na mesma linha segue o Pretório paulista: "Insistem os Impetrantes em que à Municipalidade de ... faltara competência para disciplinar o uso das praias do municipio. inserindo-se essa competência nas atribuiç̃ès da Uniäo. Laboram ém equíroco, como demonstraram com abundancia de argumentos, a abtoridade impetrada e os doutos representantes do Ministério Publico e comos deixou claro a $r$. sentença." +0 Ademais. é de se lembrar que as medidas ora cogitadas não implicam no exercício direto do poder de polícia municipal sobre as praias (o qual, vimos, também seria possível). Isto porém é verificado aus racimos nos balneários, com a Prefeitura regrando o funcionamento de barracas e al utilização da praia para prática esportiva ou para acesso de animais domésticos.

Outro ponto referir-se-ia à possibilidade de exercício do poder de polícia com vistas à proteção ambiental. A abordagem só é feita por amor ao debate. Como já nos referimos. o CTN (artigo 78) e a Lei Orgânica do Município interessado, prescrevem que a abrangência do poder de polícia municipal abarea a proteção do meio ambiente. Esta é, aliás, a imposição ditada pelo artigo 225 da Constituição Federal ${ }^{+1}$.

No mais, a manifestação ora cogitada é plenamente consentânea com as lições da doutrina. "As limitaçôes à liberdade e à propriedade somente irão se justificar se e na medida em que os direitos coletivos e difisos - tumbém enumerados no texto constitucional, bem como interesse público primairio - postulem." 12 Inexistindo dúvidats de que a preservação ambiental cuida de interesse difuso ${ }^{\text {tj }}$ de relevo

39 Cf. "Manicipio: poder de pelicia sobre a esna costeira". RT 686, pág. 270.

40 Apelação n² 289.116. Relator Césal de Morales, in RT 5.39. págs. 93 a 95.

11 Paulo de Bessa Antunes assevera: "O legislador constiminté chém de impor um dever genérico de preseriaģão e defesa, foi mais adianté é deneminon à Administraçäo qué fossem tomadus

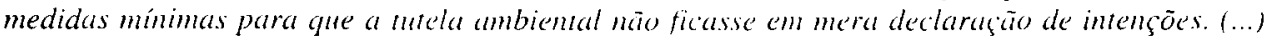
A ordem publica do meio ambiente é. findamentalmente, uma obrigaçióo estatal. O objero desta obrigaçäo se define pelo comjunto de fatos materiais que atentam contra o meio ambiente é que. em razão disto, estão submetidos à regulamentaçăo" (c)t. "Curso de Dircilo Ambiental". Rio de Janeiro, Renovar, $2^{a}$ edição, 1992, pág. 40).

42 Lúcia VALLE FIGLEIREDO, "Curso de Direito Administrativo", São Paulu, Malheiros, pág. 186.

43 Neste sentido, Raul Malta MOREIRA. "A Preservaşäo Ambiental, a Responsabilidade Ciril por Dano Ecológico e a Aluação Tutelar do Ministério Públicos". in "Temas de Direito Urbanístico", obra coletiva, São Paulo, RT, 1987, págs. 123 e segs. 
constitucional inegável. coloca-se plenamente cabível o exercício do poder de polícia neste sentido.

No caso concreto, mais que cabível, é ele imperativo. O inciso VII, do $\$ 1^{\circ}$, do mencionado artigo, da CF prevê a incumbência do Poder Público "proteger a fauna e a flora, vedadas, na forma da lei, as práticas que coloquem em risco a sua função ecológica, provoquem a extinção de espécies on submetam os animais à crueldade." Se o acesso irrestrito de veículos à regiāo propicia impacto ambiental negativo, violentando o habitat das espécies nativas ali existentes, impende a adoção de medidas restritivas, em homenagem ao mandamento constitucional.

Mais não é só. As medidas restritivas decorrem também de expressa norma municipal. A Lei Orgânica do Município interessado determina que o Município deve assegurar a restrição à utilização de áreas de riscos geológicos, o que se verifica no local pois, como já se aludiu, o volume de veículos que potencialmente acorreria ao local é incompatível com as características geológicas da Serra do Mar e do viário local, o que já levou. até mesmo. ao encrespamento do pavimento e poderá acarretar danos maiores.

Um derradeiro ponto diria respeito, outra vez. à isonomia. Poder-se-ia dizer que a adoção das medidas em cogitação seria maculada por trazer privilégios aos moradores e proprietários, que seriam beneficiados com o desfrute de um paraíso ecológico inacessível aos demais cidadãos.

O argumento é duplamente falho. Primeiro, porçue não se estaria a cogitar da vedação total do acesso à região. mas apenas da proibição do tráfego de veículos automotores, excepcionados o caso dos que lá têm casas ou terrenos ${ }^{\text {t4 }}$. Em segundo lugar, porque o privilégio decorre de situação objetiva plenamente amoldada à regra constitucional. Atinal, ninguém até hoje pleiteou isonomia com os moradores nativos da Ilha de Fernando de Noronha - à qual, salvo engano. é restritíssimo o acesso - pelo fato de poderem dispor de uma riqueza ecológica impar.

Diga-se, também, que os próprios proprietários já sofrem restrições decorrentes do poder de polícia ambiental, pois não podem dispor irrestritamente de suats propriedades (devem obedecer rígidas normas de construçào. só poder desmatar parte do terreno, têm que custear mecanismos de preservação ambiental, além de serem compelidos a pagar pesadas contribuições para manter estrutura de proteção ao meio ambiente).

Transpostos todos estes pontos. cumpre voltar à questão da implementação concreta destas medidas. Ao nosso ver, a operacionalizaçĩo do cogitado se daria mediante o estabelecimento pela Municipalidade de uma zona especial de proibição de tráfego de veículos, com o estabelecimento também, de sanções para o descumprimento da postura municipal. Tal medida normativa poderia vir acompanhada de

44 Este argumento serve também para afastar a alegaç̧ăo de que o pretendido colidiria com disposição de Lei Orgânica. que veda que loteamentos interrompam vias integrantes do sistema viário municipal. O cogitado nāo interromperia tais vias, apenas impondo uma restrição de fluxo. De outra feita, pode-se sustentar que mesmo se a restrição fusse absoluta a vedação não se aplicaria pois o viário em referência ainda não está integrado no sistema viário municipal. 
intervenções físicas voltadas a limitar tal tráfego (v.g. construção de bloqueios, cancelas, postos de físcalização, proibição de estacionamento e parada, diminuição do leito carroçável com aumento do pavimento das calçadas, construção de ciclovias, ou medidas afins).

Paralelamente, também devem ser tomadas providências no sentido de se propiciar condições para que os munícipes deixem seus veículos em local próprio (por exemplo, criando-se um bolsão de estacionamento). Ter-se-ia ainda que implementar um sistema de identificação e cadastramento dos proprietários de imóveis para que sejam emitidas credenciais que - a exemplo do que ocorre nos supracitados calçadões - permita-lhes chegar até suas casas. Por fïm, será necessário dotar a região de agentes incumbidos de coibir abusos e de intimidar o desrespeito às posturas municipais.

Convictos que estamos da legalidade de todas estas medidas. resta reconhecer a dificuldade de sua concretização em especial diante da notória carência de meios e de recursos do Poder Público municipal. E este ponto deve ser enfientado pois, como nos ensina novamente DI PIETRO, um dos requisitos que deve ser observido para validar as medidas de polícia é a eficácia, ou seja a adequação da medida para impedir o dano ao interesse público que se quer evitar. ${ }^{+5}$.

Neste passo, entendemos que nada obsta que o Poder Público municipal se socorra da comunidade (representada por sociedades amigos de bairro) para implementar as medidas que, no exercício do seu poder, venha a implementar. Ou seja, entendemos perfeitamente legal que os particulares emprestem os meios e os recursos para a implementação das medidas cogitadas. Tal cooperação. aliás, tem alrimo constitucional e legal.

Constitucional, porque o artigo 225, caput, da CF prescreve que o dever de defender o meio ambiente impõe-se, concorrentemente, ao poder público e à coletividade $^{46}$. Legal, porque diversos são os dispositivos de Leis Orgânicats de Municípios que prescrevem o princípio da participação da comunidade na implementação das diretrizes municipais. De se transcrever alguns deles: "assegurada a participação das entidades comunitárias no estudo, encaminhamento e soluções dos problemas vivenciados no municipio"; "dever do Municipio em buscar a cooperação das associações representativas no planejamento municipal"; "a meta de incentivar $e$ auxiliar as associaçōes de proteção ambiental".

Além disso, este concurso dos agentes privados se põe absolutamente consentâneo com as mais hodiernas tendências do Direito Público ${ }^{47}$.

45 In op. cit., loc. cit.

46 Indo o constituinte ao encontro da lição de Sérgio FERRAZ, para quem "O fundamental é que desde já nos conscientizemos de que o patrimônio ambiental, bem ao contrário do que dizem os juristas e algumas leis, não é 'res nulius', mas 'res omminiun' - coisa de todos. Todos temos interesse juridico na preservação do ambiente.", in "Responsabilidade Civil por Dano Ambiental", RDP, volume 49 e 50 , pág. 35.

47 Diogo Figueiredo Moreira NETO assevera: "Tudo concorre para que o Esıado Contemporâneo procure atuar de maneira menos autoritária e menos intervencionista, como ensina o formidável constitucionalista português, mas com o caveat: em tudo o que for possivel, desde que não 
Não se diga que o concurso da comunidade seria abjeto pois o poder de polícia é indelegável.

Em primeiro lugar deve-se fazer uma distinção entre a detença do poder de polícia e a disponibilidade dos meios para o exercício deste poder. Se não se pode transferir a autoridade pública ao agente privado. de molde que esta imponhat sacrifícios ou restrições aos direitos dos outros particulares. nenhum óbice pode haver em a comunidade (parte do mundo privado) colocar à disposição do poder público recursos materiais para efetivar o exercício desta autoridade. É o que tem ocorrido, com crescente frequiência, por exemplo, com a doação pela comunidade de viaturas, armas ou instalações para a Polícia Militar exercitar suas funçōes policiais no interesse geral da comunidade.

Em segundo lugar, mesmo a tese da indelegabilidade deve ser vista dentro de alguns condicionantes. É o que nos ensina Cid Tomanik Pompeu para quem "é clássica a afirmação de que o poder de policia é indelegável. Convém. c'ntretanto, que, preliminarmente, tal assunto seja estudado sob dois aspectos: o da delegação genérica e o da delegação especifica. (...) De fato seria incompreensivel que o Estado, titular do poder de polícia, pudesse delegá-lo genericamente às pessoas de direito privado, tanto físicas quanto jurídicas." 48

E prossegue o autor: "Em casos especificos, entretanto, a delegação do seu exercicio sempre foi aceita, principalmente em relação às pessoas juridicas de direito privado, as quais, da mesma forma que as pessoas jurídicas públicas administrativas, são regidas pelo princípio da especialidade, isto é, só podem exercitar as atividades para as quais tenham sido constituidas. A concessão, a permissão e a delegação para o desempenho de atividades de interesse público, anteriormente a cargo do Estado, são, portanto, exemplos de delegação do exercício do poder de polícia em setores determinados, de há muito tempo aceitos pelo direito." 44

Portanto, bem entendido que a titularidade do poder de polícia deve sempre permanecer com a Administração, nada obsta que as providências para a efetivação deste poder seja trespassada ao particular. E menos óbice ainda há em que os particulares concorram com os meios necessários para o exercício desta atividade.

Posto isto, sugeriríamos que fosse firmado convênio entre as municipalidades e as sociedades amigos de bairro de molde a que estas fornecessem os meios necessários à efetivação das restrições editadas por aquelas no exercício do seu poder de polícia. Deste convênio poderiam constar, entre outras, as obrigações dos parti-

comprometa o núcleo fundante da identidade constitucional, aduzindo-se, assim, o máximo de participação, de consenso e de colaboração da sociedade; como em todo, através de seus diversificadíssimos segmentos ou por seus indivíduos." (in "O Sistema da Parceria entre os Setores Público e Privado", BDA, fevereiro 97, pág. 77.

48 "O Exercício do Poder de Polícia pelas Empresas Públicas", in Revista Forense, volume 258, págs. 438 e 439.

49 Op. cit.. loc. cit. Neste sentido, ver também Carlos Ari SUNDFELD "Empresa Estatal Pode Exercer o Poder de Policia", in BDA, volume 02/93. págs. 98 e segs. 
culares i) realizarem as obras necessárias à restrição do tráfego: ii) cederem instalações e veículos para os aggentes da fiscalização municipal ou para eventualmente o corpo policial que se fizer necessário em momentos de maior movimento: iii) disponibilizarem funcionários seus para o apoio dos agentes públicos: iv) assumirem compromissos de preservação e conservação do meio ambiente nativo ou ainda $v$ ) se obrigarem a construir e ceder ao município um bolsão de estacionamento externo à área protegida para a parada dos automóveis que para lá rumarem.

Todas estas iniciativas, repetimos. em nada ferem a lei ou a indelegabilidade do poder de polícia que se manifesta. frise-se, na imposição da restrição do uso do viário e do condicionamento do acesso àqueles bens públicos e não na propriedade dos meios materiais para fazer cumprir tal imposição.

Muito se controverte na doutrina acerca da necessidade ou não de lei específica para legitimar o exercício concreto do poder de policia. O tema já ensejou grandes polêmicas. É plenamente sustentável que as restrições em apreço sejam impostats por Decreto ou mesmo por ato normativo inferior. Cono nos ensina Eros Grau. "o poder de polícia, em verdade, não é nem prerrogativa nem mera faculdade da Administração, porém finção dela, dever-poder que rincula sua vontade. Daí dela dizermos que consubstancia atividade sub-legal.".so. Mesmo que se exigisse a previsão legal genérica para o seu exercício ${ }^{51}$, poderia in casu a Administração exercer seu poder de polícia, descarecendo de lei específica porquanto já existe no Município norma genérica atribuindo tal prerrogativa ${ }^{52}$.

Não obstante todos estes argumentos, seria de cautela que tais medidas contassem com o beneplácito da aprovação legislativa específica. Vários fatores nos levam a adotar esta posição.

A uma, por conta do sempre convincente escólio de José Afonso Da Silva, para quem o exercício do poder de "polícia especial, seja porque tem por objeto matéria diversa da segurança, da tranqüilidade e da salubridade, enfim, matéria diferente do conceito tradicional da ordem páblica, seja porque está sujeita a um regime jurídico particular, (...) subordina-se a uma prèisão legal muito mais estreita." 53

A duas, porque, como dissemos há pouco, sempre haverá quem vislumbre uma delegação de poder de polícia. E se é assim, teríamos que recorrer ao ensino de Cid Tomanik Pompeu, para quem "no direito brasileiro, se admite, mediante norma

50 Eros Roberto GRAL. "Poder de Policia: Função Administrativa e Principio da Legalidade". RTDP, Malleiros, volume 01, pág. 90.

51 Caío TÁCITO sustenta que "o exercicio do poder de policia pressupóe. incialmente, ama autorização legal explícita on implícita atribuindo a um determinado órgão ou agente administrativo a faculdade de agir. A competência é sempre condição vinculada dos atos administrativos, decorrentes necessariamente de prévia enunciaçăo legal." (cf. "Direito Administrativa", 1975, pág. 142).

52 A previsão legislativa genérica já existe. pois como já apontamos a LOMG atutoriza o Poder Executivo a exercer o seu poder de polícia fazendo cessar as atividades que ponham em risco interesses da coletividade (artigo 10, inciso XXVIII).

53 In "Poder de Polícia", RDA, volume 137, 1978, pág. 246. 
legal expressa, a atribuição de competência para oxercicio de atividade de polícia até mesmo a pessoas privadas, quando no exercício de uma função pública." 54

Por fïm, porque para o cogitado haverá a necessidade do Município firmar convênio com a Sociedade Amigos de Bairro. E a Lei Orgânica exige a autorização legislativa para que o Poder Executivo firme convênio com particulares.

O último ponto a ser superado nesta primeira alternativa diz respeito à eventual alegação de que para a assinatura do referido convênio far-se-ia necessária a previa realização de licitação pública. Não concordamos com a exigibilidade de tal providência.

No regime legal brasileiro é indesviável a realização de licitação pública para as obras, serviços, compras, allienações, concessões. permissōes e locações promovidas pela a Administração pública (cf. artigo 37, XXI da CF e artigo $2^{\circ}$, caput da Lei n 8.666/93, Lei Federal de Licitações).

Porém, no caso, a relação convenial que se quer firmar não se enquadra em qualquer destas hipóteses. Isto porque. ao que nos parrece. não estar-se-ia a envolver qualquer dispêndio financeiro, nem tampouco contrapartida econômica por parte do Município.

Note-se que o artigo 116 da citada lei federal de licitações cuida de convênios nos quais o Poder Público assume obrigações financeirals. Tunto é assin que no seu $\S 3^{\circ}$ contém a referência à liberação das parcelas financeiras cabentes ao poder público ${ }^{55}$. E explicitamente o $\$ 6^{\circ}$ alude ao dever de se transferir ao órgão ou entidade repassador os saldos financeiros remanescentes do convênio, o que não permite dúvidas de que o convênio submetido à lei de licitações é aquele que envolve liberação de recursos financeiros por parte da Administração pública.

Como o que ocorreria in casu é justamente o inverso -- cessão pelos particulares de meios para efetivação do poder de polícia - restaria afuastada a hipótese de licitação. Afinal, exigi-la na espécie seria o mesmo que torná-la obrigatória sempre que um particular benemérito desejasse fazer doação incondicionada a ente público.

Ademais, como pouco adiante teremos al oportunidade de expor, mesmo que fosse aplicável a exigência genérica de licitar. no calso seria a mesma inexigível à luz do disposto no caput do artigo 25 da lei federal. O único agente privado em condições objetivas e subjetivas de aceitar fornecer os meios necessários à proteção ambiental em tela é a associação de moradores do local. Portanto, é o objeto impossível de competição, fazendo inoportuna e inexigível a licitação.

Resumindo a primeira alternativa. ela materializar-se-ia da seguinte forma:

i) aprovar-se-ia lei municipal instituindo na região uma área de proteção ambiental especial - prevista na Lei Orgânica - e autorizando a restrição do acesso de veículos às vias de acesso à praia;

ii) na referida lei seriam estabelecidas regras para tal restrição e sanções para o seu descumprimento;

54 In "Poder de Policia e Empresa Píblica". O Estado de Sĩo Paulo de 02.08.77, pág. 32.

55 Referências semelhantes existem nos incisos IV e $V$ do $\$ 1^{\circ}$ deste mesmo artigo 116. 
iii) no mesmo diploma estaria contida autorização para o Município fïrmar convênios com Associações e Sociedades Amigos de Bairro nos quais estas entidades assumiriam como obrigação fornecer os meios necessários para a efetivação dos atos de polícia, bem como se comprometeriam à preservação e ao uso condicionado de suals propriedades:

iv) firmado o convênio. seriam efetuadas as intervenções necessárias para fazer cumprir as restrições e os condicionamentos referidos, as quais poderiam compreender a construção e doação pelos particulares de bolsão de estacionamento externo à área, construção de bloqueios de tráfego etc:;

v) implementadas estas providências, instituir-se-iam mecanismos de relacionamento entre os agentes da autoridade pública e os funcionários da associação conveniada com vistas a otimizar e efetivar o cumprimento das restrições.

Esta seria a primeira alternativa. Outria há.

A hipótese de cessão de uso privativo e condicionado de bem público

A segunda hipótese de que cogitamos é mais simples, mas nem por isto menos polêmica. Em gênero ela se revelaria na outorga aos particulares proprietários de imóveis do direito de uso privativo dos bens públicos integrantes do loteamento, incluindo o viário. Tal outorga seria condicionada ao atendimento de uma série de cláusulas-obrigação que iriam desde a conservação dos bens e preservação do meio ambiente nativo até o impedimento de restrição do acesso de turistas desde que não motorizados e respeitantes das normas de utilização da área ambiental.

Esta atribuição genérica de uso privativo desdobrar-se-ia em duas alternativas de instrumento jurídico, a saber: a) a concessão administrativa dos bens; e b) a permissão de uso dos mesmos. Enfocaremos os prós e os contras de ambos. Antes cumpre fazer uma breve digressão acerca do uso privativo em gênero.

A hipótese de uso privativo de bem público por particular não assusta quem conhece um pouco de Direito Administrativo. Maria Sylvia Z. DI PIETRO ensina que "o uso privativo, que algans denominam uso especial, é o que a Administração Pública confere, mediante título juridico individual, a pessoa ou grupo de pessoas determinadas, para que o exerçam, com exclusividade sobre parcela do bem público." 56

E prossegue a administrativista afirmando que "o conteúdo do uso privativo é variável, podendo comportar faculdade de ocupação (como a instalação de bancas na calçada), poderes de transformação (construção de vestiários na praia) ou até

56 In “Curso ...". 4 a edição, pág. 443. 
poderes de disposição de uma parte da matéria (aproveitamento das águas ou extração de areia).

Todo e qualquer bem público (seja dominical de uso comum ou de uso especial $^{57}$ ) pode ser trespassado alo uso exclusivo de particulares. É o gue: "Todos os bens públicos, qualquer que seja a sua natureza, são passíveis de uso especial por particulares, desde que a utilização consentida nãos o lèe à inutiliaķä́o ou destruição, caso em que se converteria em alienaçăa. "ix

Pois bem, visto que o direito brasileiro não afasta a possibilidade de uso privativo de bem público, mesmo aqueles classificados como de uso comum, ou seja, afetados para alguma finalidade coletiva, impende expor individualmente cada um dos mecanismos de outorga deste uso exclusivo antes referidos.

A permissão de uso. na definição da doutrina é "o ato administrativo unilateral, discricionário e precário, gratuito on oneroso. pelo qual a Administraçäo Príblica faculta ao particular a execuşüo de serviço público on a utilizaşüo privativa de bem público. ${ }^{.54}$ Caracteriza-se, especialmente, pela suli precariedade e pelo fato de não ter, no entender da doutrina, caráter contratual ${ }^{(1)}$. pois decorre de uma outorga unilateral do poder permitente, retomável a qualquer tempo.

No caso em estudo, teria por vantagem descarecer de aprovação legislativa (previsão na Lei Orgânica). Mas leria por desvantagem al slla precariedide (Lei Orgânica) a qual não se coadunaria com as condições que motivariam a outorga do uso privativo (v.g. empenhar esforços e investimentos aptos a garantir a preservação do meio ambiente nativo e o regramento do uso da região).

Embora seja objeto de polêmica conceitual. a concessão de uso pode ser delineada como "o contrato administrativo pelo qual a Administração faculta ao particular a utilização privativa de bem público. para que a exerça conforme sua destinação."

Entendemos que este seria o instituto mais adequado ao caso. $\mathrm{O}$ uso privativo se faz necessário tendo em vista a necessidade de se adotar medidas (entre elas a restrição do acesso) com vistas à proteção ambiental. Para atingir tais objetivos, a associação comunitária terá que cumprir metals e realizar investimentos que só se viabilizam se for fixado previamente um prazo razoável para a outorga deste uso. Além disso, temos que ter em vista que os bens a serem cuncedidos são. em sua maioria, bens de uso comum, o que poderia trazer questionamentos quanto à sua desafetação. Tais questionamentos perdem sustento se adotado o instituto em apreço.

57 Quanto à classificação dos bens públicos, ver Lúcia Valle Figueiredo, op. cit., pág. 349.

58 "Direito Municipal Brasileiro", cit., pág. 229. E mais, ensinava o mestre que "o que tipifica o uso especial é a privatividade da utilização do bèn público ... pélo beneliciário do ato uu do contrato afastando a fruição geral e indiscriminada da coletividade c do próprio poder público."

59 Maria Sylvia Z. Di Pietro. "Uso Privativo de Bem Público por Particular", São Paulo, RT, 1983, pág. 71.

60 Em sentido distinto veja-se Hely Lopes Meirelles, ("Dircito Municipal", pág. 231) para quem é admissível a permissão de uso especial com prazo fíxado.

61 Idem, pág. 86. 
De fato. nenhum óbice poderá ser levantado se a Lei Orgânica estabelecer que:

1. O uso de bens municipais, por terceiros, só poderá ser feito mediante concessão administrativa. ou permissĩo al título precírio e por tempo determinado, conforme 0 interesse público o exigir.

2. A concessão administrativa de bens públicos de uso comum, somente poderá ser outorgada para finalidade escolar, de assistência social, turística, de preservação do meio ambiente e do patrimônio histórico-cultural, mediante autorização legislativa.

Dado o enquadramento da hipótese cogitada, parece-nos tocalmente recomendável no calso a adoção da hipótese de concessão.

E por admitir a LOM a hipótese de concessão de bem público de uso comum para a finalidade aqui premente. afasta-se o problema da desafetação prévia do bem, pois que não será a mesma necessária.

Como é sabido. a desafetação "é a mudança da destinaşăo do be'm. De regra, a desafetação visa a incluir bens de uso comum do poro ou bens de uso especial na categoria de bens dominicais para possibilitar a alienação."

Como na hipótese cogitada estar-se-ia concedendo o bem de uso comum afetado portanto - e como não se trata de alienação, mas apenas da outorga de uso privativo, não há porque se falar em desafetação. Apenas deve ser ressalvado que o particular concessionário estaria obrigado, entre outras coisas, a não alterar, jamais, a destinação do bem, sob pena da caducidade da concessão e consequiente retomada imediata do bem pelo Poder Concedente.

Já afirmamos que a concessão necessita de aprovação legislativa. Não fusse a doutrina em uníssono, seria o permissivo legal acimal citado a exigir. No nosso entender, a lei em tela não deve se limitar a autorizar a concessão dos bens. Deveria também prescrever os termos e as condições genéricals pelas guais se dará a outorga.

Certo é que não será na lei que serão detallhadas obrigąçôes e especificidades decorrentes da outorga. Porém, parece-nos conveniente que o legislador preveja: i) a obrigação precípua do concessionário preservar o meio ambiente nativo; ii) a garantia de acesso, ainda que condicionado, de quem pretenda usufruir da praia e da reserva de fauna e flora; iii) as incumbências, atividades e melhorias que deverão ser implementadas ou mantidas pelo concessionário: iv) a obrigação de não alterar a destinação e a condição dos bens concedidos, além do dever de preservá-los.

Um último ponto deve ser abordado. Também nesta hipótese, no nosso sentir, não se coloca exigível licitação pública. O já citaldo artigo $2^{\circ}$ da lei de licitações prescreve o dever de licitar, mas ressalva expressamente as hipóteses previstas em lei. 
Dentre estas hipóteses está aquela em que a licitação é impossível pois não se pode estabelecer um nexo de competição ${ }^{6.3}$.

No caso em estudo, vê-se que a lei municipal só autoriza a concessão de bem público de uso comum em algumas hipóteses e para algumas finalidades, dentre elas a preservação ambiental. É o atingimento desta finalidade de interesse públicu que legitima a concessão. Ora, se assim é. qualquer outro interessado na concessão se por hipótese absurda algum houvesse - não lograria dar à outorga a finalidade que a sustenta, fazendo pois inviável e ilegal a realização do objeto pretensamente licitado.

Sendo a licitação impossível - pois que afora a associação de moradores ninguém mais preenche as condições necessárias para justificar a concessão - não pode ela ser exigida, calhando à perfeição o disposto no artigo 25, caput do estatuto federal.

Resumindo a segunda linha de altemativas, temos que:

i) poderia a Municipalidade conceder, mediante autorização legislativa específica, o direito de uso privativo dos bens públicos existentes no loteamento, em especial o viário; esta concessão seria condicionada, ou se quisermos, clausuladia. conforme expusemos anteriormente;

iii) tal concessão teria um prazo previamente fixado nat lei;

iv) à associação de moradores seria outorgado o direito de uso privativo daqueles bens consoante algumas contra-prestações, em linhas gerais as segs.: a) preservar o meio ambiente nativo, fiscalizando e agindo para evitar violações à fauna e à flora; b) permitir, dentro de certas regulamentações, o acesso de turistas à praia e à região preservada; c) não alterar a destinação dos bens concedidos; d) conservar os bens objetu da concessão, procedendo às obras e serviços que se fizer necessários a impedir o seu perecimento; e) adotar todas as providências de ordem pública voltadis a manter o ambiente, a segurança e a ordem do local. dentro da sua esfera de possibilidades;

v) por fim, tal concessão prescindiria de licitação por ser a realização de certame um óbice à legalidade da outorga.

E assim concluímos o presente estudo, esperando que o desenvolvimento das duas alternativas por nós lobrigadas permita o desate justo e adequado do conflito hoje existente.

63 Sobre o tema, ver o nosso artigo "Contrataçăo Direla de Empresiats de Engenharia Consulliva por lnexigibilidade de Licitação Páblica". in RT 713. março 95. píg. 24 a seğs.. 


\section{O Estado na Preservação de Bens Culturais \\ O Tombamento}

Sonia Rabello de Castro

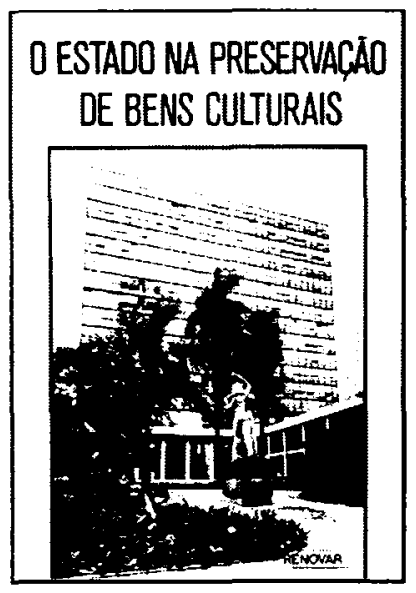

Esta obra trata do instituto jurídico do tombamento, explorando e reportando a experiência judicial brasileira na área, bem como analisando as formas e limites da atuação do Estado na preservação do nosso Patrimônio Cultural. Enfim, é uma visão crítica do instituto do tombamento a partir da própria lei, e de sua leitura pela doutrina e jurisprudência nacionais.

Ref. 0035

Form. 14x21

Brochura

1991

158 págs.

\section{O Jeito na Cultura Jurídica Brasileira}

Keith S. Rosenn

Esta obra destaca as vertentes positivas e negativas do uso do "jeito" no Brasil nos tribunais, na administração e na vida econômica e política do país em geral. Em alguns dos seus aspectos, reflete uma fase já ultrapassada da nossa história, na qual o país ainda era dominado pelo paternalismo e corrompido pela infração, mas, em outros, apresenta problemas ainda atuais e que necessitam de soluçāo urgente.

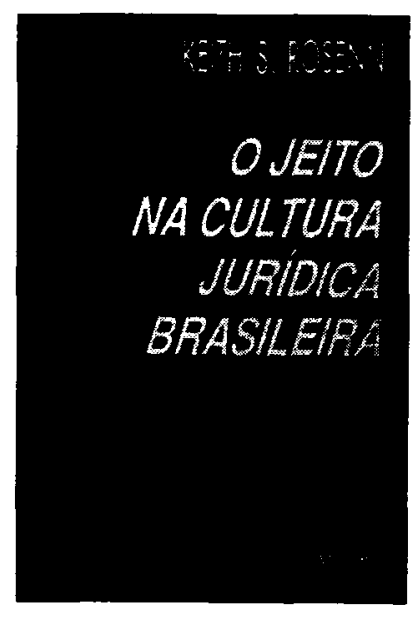

Ref. 0179

Brochura

Form. 14x21 1998

138 págs. 